Observatory, Geneva; Johannes Iapetus Smith Steenstrup, Professor of Zoology at Copenhagen, were balloted for, and declared duly elected Foreign Honorary Fellows of the Society.

The Hon. Justice Grove, M.A., D.C.L., LL.D., and the Rev. George Salmon, D.D., D.C.L., LL.D., Regius Professor of Divinity, Trinity College, Dublin, were balloted for, and declared duly elected British Honorary Fellows of the Society.

Monday, 7th February 1881.

Professor DOUGLAS MACLAGAN, Vice-President. in the Chair.

The Chairman read Obituary Notices of Mr Thomas Key. Dr William Lassell, Mr Maurice Lothian, Mr Mungo Ponton, Mr Thomas Knox, The Hon. Lord Ormidale, Professor Sharpey - deceased Fellows of the Society.

\title{
OBITUARY NOTICES.
}

Thomas Key. By J. Sanderson, Deputy Inspector-General of Hospitals.

Mr Thomas Kex, Licentiate of the College of Surgeons of Edinburgh, was a son of Dr Patrick Key, Physician in Forfar. He was born in that town in 1803 , and received his early education there. $\mathrm{He}$ attended the literary classes at the St Andrews University before coming to the University of Edinburgh to study medicine. At the age of nineteen he received his diploma of Surgeon from the College of Surgeons of that city. In the following year he received the appointment of assistant-surgeon in the Madras Medical Service of the Honourable the East India Conpany.

Very shortly after his arrival in India, he was appointed to the Hydrabad Contingent Forces in the Deccan, in which he served sixteen years. During this time he held the office of medical storekeeper, and was also superintendent of the Medical School at Bolarum, which position he held till 1842. In that year he was compelled, from the state of his health, to resign his office and return to Europe.

VOL. XI. 
During his service in the Nizam's Army in the Deccan, he several times received the thanks of the Resident for the efficient manner in which he had discharged his official duties, and also for having introduced a method of preparing certain medicines, which rendered it unnecessary to procure supplies of them from England.

While at home he attended the classes of Materia Medica and Pharmacy and Chemistry in the Edinburgh University.

In 1845 he returned to India, and was called upon to do military duties with a native regiment for a short time.

In 1846 he was appointed Professor of Chemistry and Materia Medica to the Madras Medical School, of which school he became, in 1849 , superintendent. When in that position he published a Manual of Chemistry for the use of the students, a second edition of which was called for in 1852 .

He forwarded to the great Exhibition of 1851 specimens of Fixed Oils which he had prepared, and for which he had the honour of having awarded to him by the Commissioners one of the Medals of Merit of the Exhibition.

On promotion to the superintending surgeon grade, he ceased by the existing rules of the service to be longer attached to the Medical school, and discharged the duties of this office in the above capacity till his health compelled him to leave India in 1854.

During his residence at Madras he devoted much time to several institutions, among which may be mentioned the Military' Male Orphan Asylum; the Monegar Choultry, an institution for the medical treatment of the native poor, of which he was secretary and treasurer for seven years; and the Madras Medical Fund, of which he was secretary for four years.

For his very valuable services in these capacities, he had the honour of receiving, on his retirement from the service, the thanks of the Government and of the Boards of these institutions.

Since 1854 he resided chiefly at Edinburgh. He was elected a Fellow of the Society in 1868, and died suddenly at Edinburgh on Sunday, 18th January 1880, at the age of 76 . 